\title{
BIMBINGAN KELOMPOK BERBASIS ISLAM UNTUK MENINGKATKAN PENYESUAIAN DIRI SISWA
}

\author{
Isti Bandini ${ }^{1}$, Nurus Sa'adah ${ }^{2}$ \\ UIN Sunan Kalijaga Yogyakarta ${ }^{1}$, UIN Sunan Kalijaga Yogyakarta ${ }^{2}$ \\ istibandini@gmail.com ${ }^{1}$, nurus.sa'adah@uin-suka.ac.id ${ }^{2}$
}

\begin{abstract}
ABSTRAK
Pesantren merupakan pilihan yang tepat dalam pembentukan karakter anak usia remaja, namun sebagian santri mengindikasikan kurangnya penyesuaian diri sehingga perlu diberikan bimbingan kelompok berbasis Islam. Tujuan penelitian ini adalah untuk mengetahui apakah layanan bimbingan kelompok berbasis Islam dapat meningkatkan penyesuaian diri siswa kelas VII MTs N Wonokromo yang tinggal di pondok pesantren. Hasil penelitian menunjukkan peningkatan sebelum diberikan bimbingan kelompok berbasis Islam siswa santri memiliki tingkat penyesuian diri dengan kriteria rata-rata sedang yaitu $60,26 \%$, sesudah diberikan bimbingan kelompok berbasis Islam kemampuan penyesuaian diri santri menjadi tinggi yaitu $74,38 \%$. Dengan demikian terjadi peningkatan sebesar $14,12 \%$ dengan tingkat signifikansi $\alpha=0,05$ atau $5 \%$. Peningkatan tersebut meliputi aspek penyesuaian diri sebagai adaptasi (adaptation) sebesar 15,39\%, penyesuaian diri sebagai konformitas (conformity) sebesar 13,05\%, dan penyesuaian diri sebagai penguasaan (mastery) sebesar 13,20\%. Analisis Wilcoxon tentang upaya meningkatkan penyesuaian diri siswa santri melalui bimbingan kelompok berbasis Islam pada siswa kelas VII MTsN Wonokromo yang tinggal di pondok pesantren menunjukkan hasil uji dengan harga $Z_{\text {hitung }}$ 4,937 lebih besar dari $Z_{\text {tabel }}$ 1,96 dengan demikian maka $\mathrm{Ha}$ diterima dan Ho ditolak. Hasil tersebut menunjukkan kemampuan penyesuaian diri siswa santri meningkat setelah memperoleh layanan bimbingan kelompok berbasis Islam. Dengan kata lain, penyesuaian diri siswa santri dapat meningkat setelah mendapatkan layanan bimbingan kelompok berbasis Islam.
\end{abstract}

Kata kunci : Penyesuaian Diri, Pesanren, Bimbingan Kelompok Berbasis Islam

\section{PENDAHULUAN}

Salah satu lembaga pendidikan yang menawarkan beberapa fasilitas pendidikan adalah pondok pesantren atau sekolah yang bermitra dengan pondok pesantren. Pesantren adalah sebuah kawasan yang khas yang ciri-cirinya tidak dimiliki oleh kawasan yang lain. Adapun unsur-unsur yang terdapat dalam sistem pendidikan pesantren secara tradisional yang menjadikannya khas adalah kiai, santri, masjid, pondok dan pengajaran kitab-kitab klasik. Secara garis besar, tipologi pesantren bisa dibedakan paling tidak menjadi tiga jenis, walaupun agak sulit untuk membedakan secara ekstrim diantara tipe-tipe tersebut yaitu salafiyah (tradisional), khalafiyah (modern) dan terpadu. Salafiyah adalah tipe pesantren yang hanya mengajarkan ilmuilmu agama Islam, atau kitab-kiab klasik yang ditulis oleh para ulama terdahulu. Metode pengajaran yang digunakan hanyalah metode bandongan, sorogan, hafalan dan 
musyawarah. Khalafiyah adalah tipe pesantren modern, yang di dalamnya mengajarkan ilmu-ilmu agama Islam dan ilmu-ilmu pengetahuan umum, tetapi masih tetap mengajarkan kitab-kitab klasik seperti pesantren salafiyah. Pola kepemimpinan pesantren tipe ini biasanya kolektif-demokratis, sehingga tugas dan wewenang telah dideskripsikan secara jelas, sehingga tidak ada pemusatan keputusan pada figur seorang kiai. Sistem yang digunakan adalah sistem klasikal, dan evaluasi yang digunakan telah memiliki standar yang jelas dan modern. Pesantren salafiyah atau tradisional adalah model pesantren yang muncul pertama kali. Pesantren ini biasanya berada di pedesaan, sehingga warna yang muncul adalah kesederhanaan, kebersahajaan dan keikhlasan yang murni. Tetapi seiring perkembangan zaman maka pesantren juga harus mau beradaptasi dan mengadopsi pemikiran-pemikiran baru yang berkaitan dengan sistem pendidikan yang meliputi banyak hal misalnya tentang kurikulum, pola kepemimpinan yang demokratis-kolektif. Walaupun perubahan itu kadang tidak dikehendaki, karena akan berpengaruh terhadap eksistensi kiai sendiri, misalnya pergeseran penghormatan dan pengaruh kepemimpinan. Ahmad Muhakamurrohman (2014) menuturkan bahwa dalam tradisi pesantren, selain diajarkan mengaji dan mengkaji ilmu agama, para santri diajarkan pula mengamalkan serta bertanggung jawab atas apa yang telah dipelajari. Pesantren juga mengajarkan nilai-nilai kesederhanaan, kemandirian, semangat kerja sama, solidaritas, dan keikhlasan. Kesederhanaan menunjukkan pengunduran diri dari ikatan-ikatan dan hirarki-hirarki masyarakat setempat, dan pencarian suatu makna kehidupan yang lebih dalam yang terkandung dalam hubungan-hubungan sosial.

Berdasarkan pada observasi, wawancara dan data Bimbingan dan Konseling (BK) terdapat beberapa perilaku sebagian siswa siswa santri yang mengindikasikan kurangnya penyesuaian diri siswa siswa santri pada tahun pertama di pesantren yaitu terserang berbagai macam penyakit, malas belajar, sering tidur dikelas, masalah pertemanan, mengisolasi diri dan sulit bekerjasama dalam kelompok, ghoshob, syndrom kangen dengan orang tua, perbedaan orientasi dengan orang tua yaitu belajar di pondok pesantren bukan atas kehendak sendiri tetapi karena arahan orang tua, kabur dari pesantren.

Masalah yang dibahas dalam penelitian ini dibatasi pada upaya meningkatkan penyesuaian diri santri. Dengan adanya berbagai masalah pada santri tingkat awal atau kelas VII tersebut, bimbingan yang selama ini mengandalkan ketundukan dan kepatuhan kepada kyai dan pengurus pondok, perlu diberi jenis bimbingan lain yang diharapkan dapat membantu siswa santri tingkat awal yang kurang bisa menyesuaikan diri. Salah satu upaya yang perlu dilakukan yaitu dengan menerapkan bimbingan kelompok berbasis Islam yakni bimbingan kelompok yang materinya diisi dengan konsep-konsep yang Islami.

Tujuan penelitian ini adalah untuk mengetahui apakah layanan bimbingan kelompok berbasis Islam dapat meningkatkan penyesuaian diri siswa yang tinggal di pondok pesantren. Schneiders menjelaskan bahwa penyesuaian diri dapat ditinjau dari tiga sudut pandang yaitu: (1) penyesuaian diri sebagai adaptasi (adaptation), (2) penyesuaian diri sebagai bentuk konformitas (conformity), dan (3) penyesuaian diri sebagai usaha penguasaan (mastery) terhadap suatu hal. Bimbingan konseling berbais Islam bertujuan untuk meingkatkan penyesuaian diri di pondok pesantren yaitu suatu usaha atau proses yang dilakukan oleh siswa santri dalam keadaan di lingkungan dan budaya pondok pesantren yang baru dikenalnya yang bertujuan untuk mencapai suatu hubungan yang harmonis antara lingkungan dan budaya pondok pesantren yang baru dengan individu tersebut. Lingkungan pondok pesantren bukan saja perpaduan antara lingkungan rumah dan lingkungan sekolah, namun lebih kompleks dari hal tersebut. Dengan budaya pondok pesantren yang berbeda dengan budaya di rumah atau di sekolah, maka banyak hal baru yang dirasakan oleh siswa santri pada tingkat awal. 
Budaya serba antri dalam setiap melakukan kegiatan, dari antri mandi, makan, termasuk antri ketika melakukan setoran hafalan kepada kyai atau pengurus pondok. Mereka membutuhkan bimbingan untuk menyesuaikan diri dengan semua itu, kaitannya dengan penyesuaian diri sebagai bentuk adaptasi (adaptation), konformitas (conformity) dan penyesuaian diri sebagai usaha penguasaan (mastery).

Faqih (2004) menyatakan bimbingan keagamaan berbasis islami ialah proses pemberian bantuan terhadap individu agar dalam kehidupan keagamaannya senantiasa selaras dengan ketentuan dan petunjuk Allah, sehingga dapat mencapai kebahagiaan hidup di dunia dan akhirat. Sutoyo menyatakan hakikat bimbingan dan konseling Islami ialah upaya membantu individu belajar mengambangkan fitrah-iman dan atau kembali kepada fitrah-iman, dengan cara memberdayakan (ecpowering) fitrah-fitrah (jasmani, rohani, nafs dan iman) mempelajari dan melakukan tuntutan Allah dan rasul-Nya, agar fitrah-fitrah yang ada pada individu berkembang dan berfungsi dengan baik dan benar.

Penelitian lain yaitu Evi (2010) meneliti pengembangan model bimbingan dan konseling kelompok dengan metode sosiodrama untuk meningkatkan motivasi dan disiplin belajar siswa. Penelitian ini melibatkan siswa SMA Olahraga Negeri Sriwijaya Palembang. Febriyani (2014) meneliti bimbingan kelompok yang dihubungkan dengan peningkatan penyesuaian diri siswa. Hasil penelitian tersebut menunjukkan bahwa terdapat peningkatan penyesuaian diri siswa di sekolah sebesar $83 \%$ setelah diberikan layanan bimbingan kelompok. Beberapa penelitian tersebut menunjukkan bahwa bimbingan kelompok efektif dilakukan untuk meningkatkan penyesuaian diri siswa santri.

Anak-anak yang biasanya tinggal bersama orang tua dan tidak membiasakan diri sebelumnya akan mengalami kesulitan dalam menyesuaian diri. Dengan demikian, bagi siswa santri khususnya tingkat awal yang mengalami kesulitan dalam penyesuaian diri perlu diberi bimbingan kelompok agar mereka dapat cepat menyesuaian diri dengan kegiatan-kegiatan yang ada di pondok pesantren. Bimbingan kelompok berbasis Islam diasumsikan meningkatkan penyesuaian diri siswa santri tingkat awal, yaitu dengan pendekatan agama islam yang berdasarkan Al Qur'an dan Hadits. Penyesuaian diri dapat ditinjau dari tiga sudut pandang yaitu penyesuaian diri sebagai adaptasi (adaptation), penyesuaian diri sebagai bentuk konformitas (conformity), dan penyesuaian diri sebagai usaha penguasaan (mastery). Indikator penyesuaian diri sebagai adaptasi (adaptation) terdiri dari faktor fisiologis dan psikologis. Indikator penyesuaian diri sebagai bentuk konformitas (conformity) dapat dilihat dari perilaku moral, sosial dan emosional. Sedangkan indikator penyesuaian diri sebagai usaha penguasaan (mastery) dilihat dari sikap seseorang dalam menghindari konflik (Ali dan Asrori : 2009).

\section{METODE}

Penelitian ini termasuk dalam penelitian kuantitatif karena menekankan analisisnya pada data-data berupa angka yang diolah dengan metode statistik. Adapun desain penelitian menggunakan one group pretest post-test. Melalui desain ini penelitian dilakukan hanya pada satu kelompok dengan melakukan dua kali pengukuran yaitu $\mathrm{O}_{1}$ (pretest) untuk mengukur tingkat penyesuaian diri siswa santri sebelum diberikan layanan bimbingan kelompok berbasis Islam. Pengukuran yang kedua $\mathrm{O}_{2}$ (post-test) dilakukan untuk mengukur tingkat penyesuaian diri siswa santri setelah diberi layanan bimbingan kelompok berbasis Islam. Adanya perbedaan antara pre-test dan post-test diasumsikan sebagai efek dari perlakuan yang diberikan. Subjek dalam penelitian ini berjumlah 32 orang yang diambil dengan teknik sampling jenuh yaitu mengambil semua jumlah populasi menjadi sampel penelitian, sedangkan analisis data hasil pengukuran dilakukan Uji Wilcoxon. 


\section{HASIL DAN PEMBAHASAN}

Hasil analisis data yang dikumpulkan melalui penyebaran instrumen berupa skala penyesuaian diri diperoleh kondisi awal menunjukkan penyesuaian diri santri 30 orang berada pada kategori sedang dan 2 orang berada pada kategori rendah. Para siswa santri awalnya merasakan adanya ketidaksesuaian antara kondisi sehari-hari di rumah dengan kondisi di pesantren menghadapi tuntutan keadaan antara lain menu makanan yang lebih sederhana, antri dalam melakukan kegiatan bersama, baik ketika mau makan, mandi maupun setor hafalan kepada kyai, santri dituntut untuk lebih mandiri, dalam memenuhi kebutuhannya dilakukan sendiri tidak seperti ketika dirumah masih sering dilayani oleh orang tua. Kondisi semacam ini mendorong siswa santri untuk menghadapi tuntutan keadaan secara realistis, objektif dan rasional.

Ditinjau dari aspek penyesuaian diri, hasil penelitian menunjukkan dukungan yang positif terhadap penyesuaian diri terlihat pada kemampuan penyesuaian pribadi siswa santri menerima diri demi tercapainya hubungan yang harmonis antara dirinya dan lingkungan sekitarnya yaitu lingkungan pondok pesantren setelah mendapatkan bimbingan kelompok berbasis Islam. Sementara itu ditinjau dari aspek penyesuaian sosial, hasil penelitian juga mendukung penyesuaian diri siswa santri terlihat dari timbulnya suatu pola kebudayaan dan pola tingkah laku yang sesuai dengan aturan, hukum, adat istiadat, nilai, dan norma sosial yang berlaku di masyarakat yaitu dalam lingkungan pondok pesantren setelah menerima bimbingan kelompok berbasis Islam. Jika dikaitkan dengan penyesuaian diri yang sehat, setelah menerima bimbingan, siswa santri menunjukkan aspek penyesuaian diri yang sehat meliputi empat aspek yaitu kematangan emosional, kematangan intelektual, kematangan sosial dan tanggung jawab.

Ditinjau dari penyesuaian diri sebagai adaptasi (adaptation), penyesuaian diri dilihat dari faktor fisiologis dan psikologis. Peningkatan penyesuaian diri sebagai adaptasi sebelum siswa santri diberi bimbingan dengan sesudah diberi bimbingan kelompok berbasis Islam sebesar $15,39 \%$. Secara fisiologis santri sudah dapat menyesuaikan diri secara fisik, artinya dengan keadaan dan aturan fisik pesantren, siswa santri sudah bisa menyesuaikan diri. Contohnya menu makan yang sederhana, kegiatan antri, piket kebersihan berjalan tertib dan melaksanakan dengan senang hati. Secara psikologis, siswa santri tampak lebih senang dalam kebersamaan, saling membantu satu sama lain apabila ada yang membutuhkan bantuan.

Ditinjau dari penyesuaian diri sebagai bentuk konformitas (conformity), penyesuaian diri mencakup konformitas terhadap suatu norma baik secara moral, sosial, maupun emosional. Peningkatan penyesuaian diri sebagai bentuk konformitas sebelum siswa santri diberi bimbingan dengan sesudah diberi bimbingan kelompok berbasis Islam sebesar 13,05\%. Konformitas dalam perilaku moral terlihat dalam hal berpakaian, siswa santri lebih rapi dalam mengenakan pakaian muslim. Konformitas dalam perilaku sosial terlihat dalam sholat berjamaah dan tahajud, siswa santri lebih tertib. Sedangkan dalam perilaku emosional, siswa santri lebih bisa mengendalikan emosinya.

Ditinjau dari penyesuaian sebagai usaha penguasaan (mastery) penyesuaian diri dilihat dari kemampuan menghindari konflik-konflik, kesulitan dan frustasi, mengendalikan emosi dan memanipulasi lingkungan. Peningkatan penyesuaian diri sebagai usaha penguasaan sebelum siswa santri diberi bimbingan dengan sesudah diberi bimbingan kelompok berbasis Islam sebesar $13,10 \%$. Dengan bimbingan kelompok berbasis Islam, siswa santri sudah mulai dapat meminimalisir konflik dengan teman, misalnya mengejek ataupun menggunakan barang orang lain tanpa ijin. Dalam menghadapi kesulitan belajar, santri sudah mulai membiasakan diri bertanya kepada pengurus pondok/santri senior, untuk pelajaran umum, santri belajar bersama di madrasah, tempat mereka menimba ilmu umum. Untuk menanggulangi rasa frustasi dan stress, konselor memberikan saran melatih kedewasaan 
dalam berpikir dan selalu mensyukuri apa yang ada serta berpikir positif terhadap semua hal. Siswa santri mengendalikan keinginan-keinginan yang sifatnya hiburan. Dalam memanipulasi faktor lingkungan, siswa santri juga mulai tidak terpengaruh dengan lingkungan sekitar dan menerima tradisi yang baik di pesantren.

Tabel 1. Perubahan Skor Ditinjau dari Aspek Penyesuaian Diri

\begin{tabular}{clccc}
\hline NO & ASPEK & $\begin{array}{c}\text { SEBELUM } \\
\mathbf{( \% )}\end{array}$ & $\begin{array}{c}\text { SESUDAH } \\
\mathbf{( \% )}\end{array}$ & $\begin{array}{c}\text { PERUBAHAN } \\
\mathbf{( \% )}\end{array}$ \\
\hline 1 & Adaptasi & 61.57 & 76.96 & 15.39 \\
\hline 2 & Konformitas & 58.28 & 71.33 & 13.05 \\
\hline 3 & Mastery & 59.75 & 72.85 & 13.10 \\
\hline & Rata-rata & 60.26 & 74.38 & 14.12 \\
\hline
\end{tabular}

Sesuai dengan teori yang ada, bimbingan kelompok berbasis Islam dapat meningkatkan penyesuaian diri siswa santri pada aspek penyesuaian diri sebagai adaptation (adaptasi), conformity (konformitas) dan mastery (penguasaan) melalui layanan bimbingan kelompok berbasis Islam pada siswa kelas VII MTsN Wonokromo yang tinggal di pondok pesantren. Sebelum diberikan bimbingan kelompok berbasis Islam siswa santri memiliki tingkat penyesuian diri dengan kriteria rata-rata sedang yaitu 60,26\%, sesudah diberikan bimbingan kelompok berbasis Islam kemampuan penyesuaian diri santri menjadi tinggi 74,38\%. Dengan demikian terjadi peningkatan sebesar $14,12 \%$ berarti terjadi peningkatan yang signifikan.

Pada aspek penyesuaian diri sebagai adaptasi / adaptation, konformitas / conformity dan mastery / penguasaan melalui layanan bimbingan kelompok berbasis Islam pada siswa kelas VII MTsN Wonokromo yang tinggal di pondok pesantren. Terjadi peningkatan pada masing-masing responden karena pada saat pelaksanaan treatment mereka mengikuti layanan bimbingan kelompok berbasis Islam ini dengan penuh antusias. Masing-masing responden mengungkapkan ide, gagasan dan pikiran mereka untuk membahas materi yang sedang dibahas. Seluruh responden mengalami peningkatan skor karena pada saat pelaksanaan bimbingan kelompok berbasis Islam responden ini menampakkan sikap keterbukaan seperti mudah menerima pendapat orang lain, tidak mengabaikan masukan yang diberikan teman, mempertimbangkan sesuatu secara matang terhadap tindakan yang akan dilakukan kepada orang lain, selalu berusaha berpikir secara rasional, tetap menghargai orang lain dan bertukar pendapat dan pengalaman dengan teman untuk menambah pengetahuan. Anggota kelompok dapat memahami tentang penyesuaian diri di pondok pesantren. Dalam pelaksanaan bimbingan kelompok berbasis Islam, anggota belajar untuk memahami kesulitan berawal dari memahami penyebab hingga cara menyikapinya. Anggota kelompok juga belajar untuk mengendalikan masalah sehingga kesulitan yang muncul tidak menyebabkan masalahmasalah baru yang semakin menyulitkan. Keterlibatan masing-masing anggota membuat topik pembahasan menjadi lebih mendalam dan berdampak pada peningkatan tingkat penyesuaian diri siswa santri di pondok pesantren.

Bimbingan kelompok berbasis Islam efektif sebagai upaya dalam meningkatkan penyesuaian diri siswa santri, karena dalam kegiatan bimbingan kelompok tersebut, siswa santri diajak untuk berlatih berinteraksi dengan siswa santri lain dalam satu kelompok yang didalamnya membahas materi bimbingan yang disajikan. Dari hal tersebut siswa santri akan memperoleh berbagai pengalaman, pengetahuan dan gagasan. Dari topik itu pula siswa santri dapat belajar mengembangkan nilai-nilai yang didasarkan pada ajaran Islam dan menerapkan langkah-langkah bersama dalam menanggapi topik yang dibahas dalam bimbingan kelompok tersebut. Adapun topik-topik yang dibahas dalam Bimbingan Kelompok berbasis islami untuk meningkatkan penyesuaian diri bagi santri dalam penelitian ini yaitu : (1) Persaudaraan sesama muslim; (2) Budaya ghasab dan ruginya budaya ghasab bagi seseorang; (3) 
Kewajiban menuntut ilmu; (4) Pola hidup sederhana dan kehidupan yang seimbang (5) Pengendalian diri.

Konsep bimbingan kelompok berbasis Islam, dengan materi-materi yang disampaikan mengandung unsur ajaran agama/ke-Tuhan-an, menghubungkan dengan kehidupan setelah mati, konsep materi bimbingan didasarkan kepada Al-Qur'an dan Hadis, serta dalam prosesnya dikaitkan dengan pahala dan dosa yang telah dikerjakan. Bimbingan kelompok berbasis Islam dalam penelitian ini merupakan upaya pemberian bantuan kepada siswa santri secara kelompok untuk mengambil keputusan yang tepat dan mandiri dalam dinamika kelompok untuk mendapatkan informasi tentang peningkatan penyesuaian diri di pondok pesantren sehingga siswa santri mampu meningkatkan potensinya meskipun dalam pencapaian tujuan menemui berbagai kesulitan. Dalam pelaksanaan bimbingan kelompok ada empat tahap yaitu tahap pembentukan, tahap peralihan, tahap kegiatan, dan tahap pengakhiran.

Untuk dapat menguji hipotesis dalam penelitian ini yaitu mengetahui bahwa layanan bimbingan kelompok berbasis Islam merupakan upaya dalam meningkatkan penyesuaian diri siswa santri, digunakan uji statistik analisis Wilcoxon. Analisis Wilcoxon tentang upaya meningkatkan penyesuaian diri siswa santri melalui bimbingan kelompok berbasis Islam pada siswa kelas VII MTsN Wonokromo yang tinggal di pondok pesantren ditunjukkan berdasarkan hasil uji dimana harga $Z_{\text {hitung }} 4,937$ ternyata lebih besar dari $Z_{\text {tabel }}$ 1,96 dengan demikian maka Ha diterima dan Ho ditolak. Hasil tersebut menunjukkan kemampuan penyesuaian diri siswa santri meningkat setelah memperoleh layanan bimbingan kelompok berbasis Islam. Dengan kata lain, penyesuaian diri siswa santri dapat meningkat setelah mendapatkan layanan bimbingan kelompok berbasis Islam.

Menurut Prayitno (2012) layanan bimbingan kelompok dapat digunakan untuk mengubah dan mengembangkan sikap dan perilaku yang tidak efektif menjadi lebih efektif. Dalam hal ini lingkup kelompok memberikan motivasi kepada masing-masing anggota agar dapat memahami kesulitan yang dihadapi sebagai salah satu langkah menuju sukses. Bimbingan kelompok berbasis Islam memberikan kontribusi dalam peningkatan kemampuan penyesuaian diri siswa santri di pondok pesantren. Dalam pelaksanaan layanan bimbingan kelompok berbasis Islam di dalamnya berisi materi tentang kehidupan yang seimbang, kewajiban menuntut ilmu, menjaga kebersihan, berpakaian menurut Islam, sesama muslim bersaudara, budaya ghasab, mengendalikan diri dan pola hidup sederhana. Materi tersebut disampaikan agar siswa santri sebagai anggota kelompok akan sama-sama menciptakan dinamika kelompok yang dapat menjadikan tempat untuk mengembangkan kemampuan penyesuaian diri siswa santri di pondok pesantren. Anggota kelompok mempunyai hak sama untuk melatih diri dalam mengemukakan pendapatnya, membahas topik komunikasi antar pribadi dengan tuntas, siswa santri dapat saling bertukar informasi, memberi saran dan pengalaman. Tujuan umum dari bimbingan kelompok berbasis Islam ialah membantu individu mengembangkan hubungan vertikal (kepada Allah) dan horizontal (kepada sesama manusia) dengan memahami status dirinya dihadapan Allah dan posisinya di tengah-tengah manusia dengan segala konsekuensinya.

Bimbingan kelompok berbasis Islam dalam penelitian ini bertujuan untuk membahas topik-topik yang bersumber dari Al Qur'an dan Hadis yang mengajarkan agar siswa santri bisa menyesuaikan diri dalam lingkungan pondok pesantren, sehingga perlu diberikan bimbingan dan ditanamkan keyakinan beragama, kesadaran moral/akhlaqul karimah dan tanggung jawab sosial. Di dalamnya mencakup aspek-aspek yang berhubungan dengan penyesuaian diri terhadap lingkungan pondok pesantren. Aspek-aspek tersebut adalah penyesuaian diri sebagai adaptasi, konfornitas dan mastery. Melalui dinamika kelompok yang intensif, maka ketiga aspek tersebut mengalami peningkatan. Bimbingan kelompok merupakan layanan yang kondusif yang memberikan kesempatan bagi para anggotanya untuk 
menambah penerimaan diri dari teman yang lain, memberikan ide, perasaan, dorongan bantuan alternatif dalam mengambil keputusan yang tepat, dapat melatih perilaku baru dan bertanggung jawab atas pilihannya sendiri berdasarkan nilai-nilai ajaran Islam. Dalam kelompok, anggota belajar memahami cara pandang baru untuk meningkatkan potensi, menyikapi kesulitan, dan menciptakan kesuksesan untuk meraih kebahagiaan di dunia dan akhirat.

\section{SIMPULAN}

Terkait dengan uraian diatas, dapat disimpulkan bahwa tingkat penyesuaian diri siswa santri terhadap lingkungan pondok pesantren sebelum dan setelah memperoleh bimbingan kelompok berbasis Islam mengalami peningkatan. Dengan demikian bimbingan kelompok berbasis Islam dapat digunakan sebagai salah satu upaya dalam meningkatkan penyesuaian diri siswa kelas VII MTsN Wonokromo. Penyesuaian diri siswa santri sebelum responden memperoleh perlakuan berupa bimbingan kelompok berbasis Islam, diperoleh kriteria sedang $(60,26 \%)$. Setelah mendapatkan bimbingan kelompok berbasis Islam, kriteria meningkat menjadi tinggi (74,38\%) dengan demikian, terjadi peningkatan sebesar $14,12 \%$ dengan tingkat signifikansi $\alpha=0,05$ atau $5 \%$. Peningkatan tersebut meliputi aspek penyesuaian diri sebagai adaptasi (adaptation) sebesar 15,39\%, penyesuaian diri sebagai konformitas (conformity) sebesar 13,05\%, dan penyesuaian diri sebagai penguasaan (mastery) sebesar $13,10 \%$.

\section{DAFTAR PUSTAKA}

Ahmad Muhakamurrohman: Pesantren: Santri, Kiai, dan Tradisi (hal. 109-118) Vol. 12, No. 2, Juli - Desember 2014 ibda' Jurnal Kebudayaan Islam

Arikunto, Suharsimi, Prosedur Penelitian Suatu Pendekatan Praktik, Jakarta : Rineka Cipta, 2006

Evi, Pengembangan Model Bimbingan dan Konseling Kelompok dengan Metode Sosiodrama untuk Meningkatkan Motivasi dan Disiplin Belajar Siswa (Studi Terhadap SMA Olah Raga Negeri Sriwijaya Palembang), Bandung : UPI, 2010

Faqih, Ainur Rahim, Bimbingan dan Konseling dalam Islam, Yogyakarta : UII Press, 2004

Fatimah, Enung, Psikologi Perkembangan (Perkembangan Peserta Didik), Bandung: Pustaka Setia, 2006

Febriyani, Tika, Peningkatan Penyesuaian Diri Siswa Melalui Bimbingan Kelompok dalam Jurnal FKIP Vol. 1, Lampung : Unila, 2014

Gerungan, Psikologi Sosial, Bandung: Refika Aditama, 2009

Mohammad Ali dan Muhammad Asrori, Psikologi Remaja, (Jakarta: Bumi Aksara Cet. Ke-5, 2009), hlm. 173-175

M. Syaifuddien Zuhriy. Budaya Pesantren dan Pendidikan Karakter pada Pondok Pesantren Salaf. Walisongo jurnal penelitia sosial dan keagamaan, Volume 19, Nomor 2, November 2011 halaman 287-310 
Bimbingan Kelompok Berbasis Islam untuk Meningkatkan....

Prayitno. 2012. Seri Panduan Layanan dan Kegiatan Pendukung Konseling. Padang : FIP-UNP 